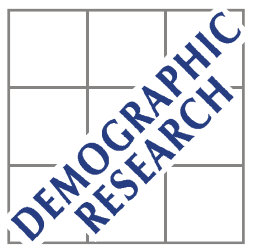

Demographic Research a free, expedited, online journal

of peer-reviewed research and commentary in the population sciences published by the Max Planck Institute for Demographic Research

Konrad-Zuse Str. 1, D-18057 Rostock · GERMANY

www.demographic-research.org

DEMOGRAPHIC RESEARCH

VOLUME 23, ARTICLE 4, PAGES 73-104

PUBLISHED 13 JULY 2010

http://www.demographic-research.org/Volumes/Vol23/4/

DOI: 10.4054/DemRes.2010.23.4

Research Article

Sibship size and status attainment

across contexts: Evidence from

the Netherlands, 1840-1925

Hilde Bras

Jan Kok

Kees Mandemakers

This publication is part of the proposed Special Collection "Social Mobility and Demographic

Behaviour: A Long-Term Perspective", organized by Guest Editors Cameron Campbell, Jan Van Bavel,

and Martin Dribe.

(C) 2010 Hilde Bras, Jan Kok \& Kees Mandemakers.

This open-access work is published under the terms of the Creative Commons Attribution NonCommercial License 2.0 Germany, which permits use, reproduction \& distribution in any medium for non-commercial purposes, provided the original author(s) and source are given credit.

See http:// creativecommons.org/licenses/by-nc/2.0/de/ 


\section{Table of Contents}

$\begin{array}{lll}1 & \text { Introduction } & 74\end{array}$

2 Understanding the effects of sibship size across contexts $\quad 75$

2.1 The developmental cycle of the household 76

2.2 Buffering: extended kin groups and social institutions 76

2.3 Industrialization and fertility decline: changes over time $\quad 77$

3 The case of the Netherlands in the long nineteenth-century 78

4 Data $\quad 81$

$5 \quad$ Measures $\quad 83$

6 Method $\quad 86$

$7 \quad$ Results $\quad 88$

7.1 Sibship size and social status at marriage: descriptive results $\quad 88$

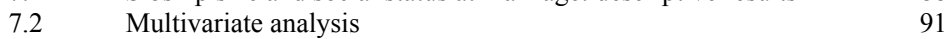

$8 \quad$ Conclusion and discussion $\quad 95$

$9 \quad$ Acknowledgements $\quad 97$

$\begin{array}{ll}\text { References } & 98\end{array}$ 


\title{
Sibship size and status attainment across contexts: Evidence from the Netherlands, 1840-1925
}

\author{
Hilde Bras ${ }^{1}$ \\ Jan Kok ${ }^{2}$ \\ Kees Mandemakers ${ }^{3}$
}

\begin{abstract}
This paper investigates the effects of sibship size on status attainment across different contexts and subgroups. Resource dilution theory predicts that with larger sibship size, children's status outcomes fall. However, the empirical record has shown that this is not always the case. In this paper we have tested three alternative hypotheses for neutral or even positive effects of sibship size on status attainment on the basis of a large-scale registry database covering the period of industrialization and fertility decline in the Netherlands in the nineteenth and early twentieth-century. Our findings offer support for the family developmental cycle, buffering by kin groups, and socio-economic development as alternative explanations to the resource dilution hypothesis.
\end{abstract}

\footnotetext{
${ }^{1}$ VU University Amsterdam, Department of Social Research Methodology, De Boelelaan 1081, 1081 HV Amsterdam, The Netherlands. E-mail: haj.bras@fsw.vu.nl.

${ }^{2}$ Virtual Knowledge Studio for the Humanities and Social Sciences (VKS) Cruquiusweg 31, 1019 AT, Amsterdam, The Netherlands. E-mail: jan.kok@vks.knaw.nl.

${ }^{3}$ Erasmus University Rotterdam and International Institute of Social History. Cruquiusweg 31, 1019 AT, Amsterdam, The Netherlands. E-mail: kma@iisg.nl.
} 


\section{Introduction}

What is the role of family structure in society? How, in particular, does the configuration of siblings influence how children's lives turn out? Contemporary research on status attainment in Western societies, whether it is geared to measuring educational achievement, intelligence, or occupational attainment, consistently demonstrates a strong negative impact of the sibship size of the family of origin on accomplishments later in life (Blake 1981, 1989; Conley 2005; Davis 1997; Downey 1995; Kasarda and Billy 1985; Steelman et al. 2002). With an increasing number of siblings, children's status outcomes consistently fall.

This record of empirical evidence confirms the resource dilution explanation - the most widely accepted theory used to explain the relationships between the basic parameters of the sibling group and children's outcomes. The resource dilution model dates back to the "law of capillary action", framed by Arsène Dumont in 1890 and stating that the presence of siblings attenuates resources necessary for social mobility. Developed in a period of demographic transition, Dumont's idea was that when parents wanted their children to be upwardly mobile, they needed to control their fertility and limit their family size. Hence, they would have to trade quantity for quality (Dumont 1890). The resource dilution hypothesis basically depicts the family as a unit that distributes valuable resources to children and this process has implications for children's status outcomes. The amount of resources that can be allocated to any given child depends both on the amount of resources in the family, and on the number of children. The larger the family is, the greater the dilution of resources and therefore the lower the eventual status of the child (Becker 1991; Downey 2001; Steelman et al. 2002).

However, over the past decades, a number of studies have presented contradictory evidence. The negative effect of sibship size on child outcomes has been found to be much weaker, neutral or even positive in some developing societies (Buchmann and Hannum 2001; Desai 1995; Eloundou-Enyegue and Williams 2006; Gomes 1984; Hermalin, Seltzer and Lin 1982; Lu and Treiman 2008; Maralani 2008; Razzaque, Streatfield and Evans 2007; Sudha 1997; Yu and Su 2006). Moreover, historical research (Adams and Kasakoff 1992; Van Bavel 2005; Wall 1996), as well as some older sociological work on social class differences in the relation between family size and status attainment (Bayer 1967; Elder 1962), provides evidence that partly refutes the resource dilution hypothesis.

These ambiguous findings suggest that there might be different mechanisms at work in the sibship size-child outcome relationship, depending on social-cultural context or subgroup membership. In the literature on sibship size, different explanations have been put forward, ranging from the developmental cycle of the household (Desai 
1995), to buffering by extended kin groups (Shavit and Pierce 1991), social institutions (Blake 1989), public policies (Park 2008), and changes in the relationship over the course of socioeconomic development and demographic transition (Maralani 2008; Van Bavel 2005). So far, however, few studies have systematically tested most of these alternative mechanisms at the same time and on the basis of one data source covering a long time span.

In this article, we study the relationship between sibship size and status attainment at marriage within different contexts and subgroups. We use a unique database, which contains indexes of more than one million marriage certificates related to five of the eleven Dutch provinces during the period between 1812-1922. Through an intricate linking procedure, the marriage records of the bride and groom and those of their parents have been connected making it possible to reconstruct the size of the bride's or groom's sibling set. In addition to the individual and parental background information from the marriage records, macro-level information on the communities in which the marriages took place was added. Our dataset thus allows for a large-scale, comparative, multilevel analysis of the relationship between family size and status attainment at marriage for a substantial part of a European population for almost a century.

In the next section we suggest three possible mechanisms through which to explain reduced negative or even positive effects of sibship size on children's status outcomes. We then describe the case of the Netherlands and formulate hypotheses pertaining to the effects of sibship size on status at marriage for different contexts and subgroups. Next, our data is introduced and we describe our measures and methods. In order to get a first impression of sibship size and status attainment at marriage in The Netherlands, we present descriptive results showing how status at marriage was associated with family size, thereby making distinctions by major subgroups and contexts. Through a series of hierarchical multilevel models, we then test our hypotheses and assess the influence of sibship size on status outcomes and how this influence diverged across contexts. In the final section, we summarize and discuss our findings.

\section{Understanding the effects of sibship size across contexts}

We present three mechanisms through which sibling structure influences status outcomes, predicting results that go (partly) against the theory that opportunities for children in large families or of higher parity are depleted by resource dilution. 


\subsection{The developmental cycle of the household}

A first, primarily economic, explanation departs from the idea of the family domestic cycle. Initially developed for the Russian peasantry, Chayanov (1966) first posited the idea that the (peasant) household can be seen as a joint unit moving across levels of well-being, governed by the ratio of consumers and producers in the household. In the beginning of the household developmental cycle, when children are small and unable to contribute to the household income, consumers outnumber producers, and household expenditure is high. As the household progresses over time and the oldest children start to participate at home, the balance between consumers and producers becomes more equal. Older children go out to work and donate their earnings to the family budget or may migrate, sending remittances to supplement the family income. At the end of the developmental cycle, producers outnumber consumers, and the family income is neutral or even higher than its costs (see also Berkner 1972).

In contexts and social groups where children become productive at an early age in order to contribute to the household income, resources available for each child are associated with sibship size in a different way than is assumed under the resource dilution hypothesis (Desai 1995). To be sure, resources are not fixed but dependent on the number of siblings and the stage in the developmental cycle. As a result, in many developing countries it is indeed found that large families (as they reflect a later phase in the family cycle) are not always disadvantageous to children, and that the work of elder children enables younger children to attend school, or to attain higher educational or occupational status (Desai 1995; Gomes 1984). Also for historical societies it has been shown that later-born children profited from the remittances brought in by older children, determining their pathways and life chances in favorable ways (Bras 2003; Bras and Kok 2003; Wall 1996).

\subsection{Buffering: extended kin groups and social institutions}

A premise of the resource dilution explanation is that parents (or the nuclear family) provide all resources. As Coleman (1988) has argued however, a lack of resources in the family might be compensated for by social capital, such as strong community bonds or extended kin ties. Social ties outside of the family thus provide a buffer for diluted resources due to large families or a disadvantageous sibling position. In many societies and social groups children receive support, not only from the nuclear family, but also from extended kin. Shavit and Pierce (1991) observed that while the size of the nuclear family had a negative effect on the educational achievement of Ashkenazi and Oriental Jews, it had no effect on the scholastic accomplishments of Moslem Arabs. The 
Moslems' extended family, or hamula, plays an active role in supporting the nuclear family. Thus, it was found that the size of the hamula positively affected educational achievement.

In past European societies, differences have been observed in the ties to extended kin and neighbours (Todd 1985, 1987, 1990). In areas where stem families dominate, the conjugal couple and their children often co-reside with parents and unmarried siblings. Stem families have close-knit social networks with many relationships among its component parts (Bott 1957). Höllinger and Haller (1990) found more frequent contact with extended kin in areas with high proportions of stem families. A study by Bras and Van Tilburg (2007), which contrasted social networks of elderly born in three regions of the Netherlands, showed larger social networks and significantly more extended kin and neighbours in the area with stem families and customs of neighbour help. The stronger bonds with extended kin and neighbours in these areas will likely have provided children with additional resources that might have buffered the potential negative effects of large family size.

Similarly, it has been shown that particular institutions or external agencies, such as the Catholic Church (Blake 1989), the Mormon community (Downey and Neubauer 1998), certain welfare regimes (Xu 2008), or national public policies (Park 2008) stimulate large families and provide incentives that offset the negative effects of large sibships. Pro-family and pronatalist norms, and financial support for large families (e.g. reduced tuition fees for children from large families in Catholic schools) might thus also provide partial protection against negative sibling structure effects.

\subsection{Industrialization and fertility decline: changes over time}

Finally, it has also been purported that the relationship between sibling configuration and child outcomes might be dependent on the degree of socio-economic development and the extent of fertility limitation of a particular society (Van Bavel 2005). In pretransition, pre-industrial societies, the effects of family size on social status would have been weak, non-existent or even positive. Over the course of socioeconomic development and as families start to limit their size, the importance of resource dilution as a mechanism for explaining the effects of sibling structure would have increased in importance. This would have resulted in an increasingly strong negative impact of sibship size over time. Empirical evidence has uncovered changing effects of sibship size over time, and has demonstrated disparate associations with attainment for rural versus urban areas, as well as modern versus traditional sectors in contemporary developing countries (Hermalin et al. 1982; Lu and Treiman 2008; Maralani 2008). For historical populations, little empirical evidence exists as yet that maps changes in the 
relationship between sibship size and child outcomes over time, as has also been observed by Van Bavel (2005). Our data set, which covers a stretch of more than 80 years, including the pre-transition and start of the fertility limitation phases in the Netherlands, will be able to shed light on this issue. In the next section, we sketch the historical background of the Netherlands and formulate hypotheses for the Dutch case.

\section{The case of the Netherlands in the long nineteenth-century}

Since the sixteenth century, the Netherlands has combined a rural, agricultural economy, with highly developed urban services. Industrialization came relatively late to the Netherlands, starting around 1860 in the urban heartland of Holland and characterized, above all, by an intensification of the tertiary sector (Van Zanden and Van Riel 2004). In the 1890s this process accelerated, and was accompanied by urbanization, massive rural-urban migration and the broadening of urban labor markets. In the five provinces for which we have data - Groningen, Overijssel, Gelderland, Zeeland, and Limburg (see dark gray area in Figure 2) - the pace of industrialization was considerably slower than in urbanized Holland. Although in the provincial towns in these regions the service-sector grew and a number of (rural) industries developed, all five regions remained highly dependent on their agricultural economies during the period of 1840-1925.

The development of average occupational status over time in Figure 1 gives an indication of the course of socioeconomic development in these provinces during the period of 1840-1925. ${ }^{4}$ The trend line shows that average status at marriage remained roughly stable during the first 25 years of the study period and started to rise as of 1865 . The increase in achieved occupational status became steeper as of 1885, and steeper still as of 1895. The development of status at marriage reflects the broader process of socio-economic development in the Netherlands, which began to accelerate in the 1890s. The trend in average sibship size in our dataset (dotted line) mirrors the shape of the fertility transition in the Netherlands. ${ }^{5}$ As a result of unchanged high fertility levels and declining mortality rates, the size of sibling sets even increased between 1885 and 1905. Strikingly, we observe that in our study area, fertility started to decline as of 1905 and to decrease more sharply after 1915 . Of course, the trend lines depicted here mask important regional differences. In the inland eastern provinces of Gelderland and

\footnotetext{
${ }^{4}$ Calculated on the basis of our data set, Genlias (version 2007_3). For an explanation of the measurement of socio-economic status see section 5 .

${ }^{5}$ One should be aware that the sibling sets studied in this paper are not complete; they do not include those siblings that never married. Taking into account that one of the children, usually the youngest daughter never married, average sibship size hovered between 4 and 5 siblings between 1840 and 1905 .
} 
Overijssel and in the southern province of Limburg, fertility decreased much later than in the southwestern province of Zeeland and in the northern province of Groningen (Boonstra and van der Woude 1984: 13).

\section{Figure 1: Average occupational status at marriage (dotted line) and average sibship size between 1840 and 1929}

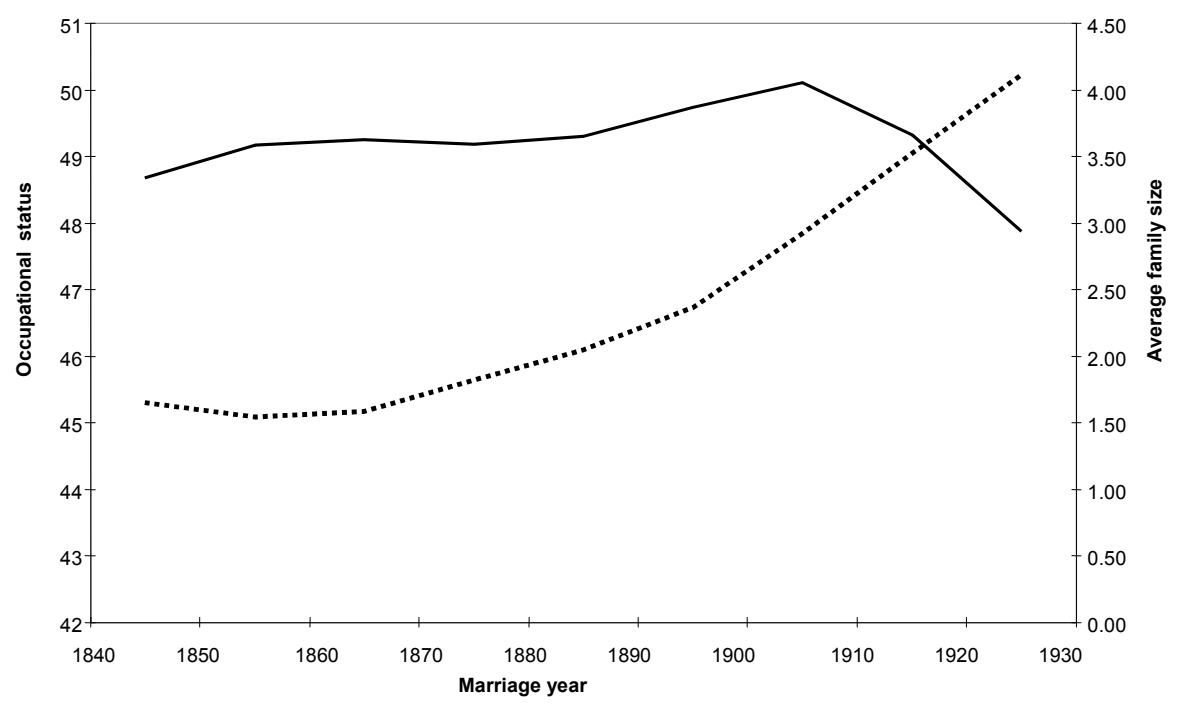

In the Netherlands, stem families and coresidence with kin were common only in certain regions. ${ }^{6}$ In the eastern part of the Netherlands, stem families were common since at least the sixteenth century (Verduin 1985: 77). Map 2 of Figure 2 shows that in 1899 this custom was still alive; particularly in Overijssel, and that Gelderland households often contained kin co-residents. Households in Groningen and Zeeland, on the contrary, traditionally not only had fewer children, but also hardly any co-resident kin (or boarders) living with them. The province of Limburg was somewhere in between. Moreover, formalized forms of neighbourly help, i.e. rules prescribing how neighbours were to help one another, had been quite common in the Netherlands. In the cities and commercialized rural areas of the north and west of the country, prescribed

\footnotetext{
${ }^{6}$ Three-generation households were created because at the marriage of one of the sons, the young couple 'married in' and became part of the parental household. This custom was connected to impartible inheritance practices, in which farm and land as a whole went to the marrying son. In return, the heir had the duty to board and lodge his unmarried siblings.
} 
neighbourly help did not survive the social polarization associated with the commercialization of these areas. In the south and east, however, neighbourly help persisted well into the late nineteenth century, (Sleebe 1998a, 1998b), more or less coinciding with the regions where stem families and household sharing with kin were common.

The Netherlands was a country of mixed religion: the southern provinces were almost completely Catholic, while to the north of the big rivers, the Reformed Church dominated, albeit with sizable Catholic enclaves in Gelderland, Overijssel and Zeeland (see map 2 in Figure 2). The Catholic Church propagated large families and Dutch Catholic organizations spread pro-natalist and pro-family norms and offered moral, and after 1917, material support to large Catholic families (Righart 1986).

Figure 2: Maps of the Netherlands in 1899 indicating the study area and (1) coresident kin (black: 1450-2580 'others' per 1000 heads; dark grey: 1200-1399 'others' by 1000 heads, light grey: 915-1199 others per 1000 heads); (2) Catholicism (black: municipalities in the top 25\% in terms of proportions of Catholics)
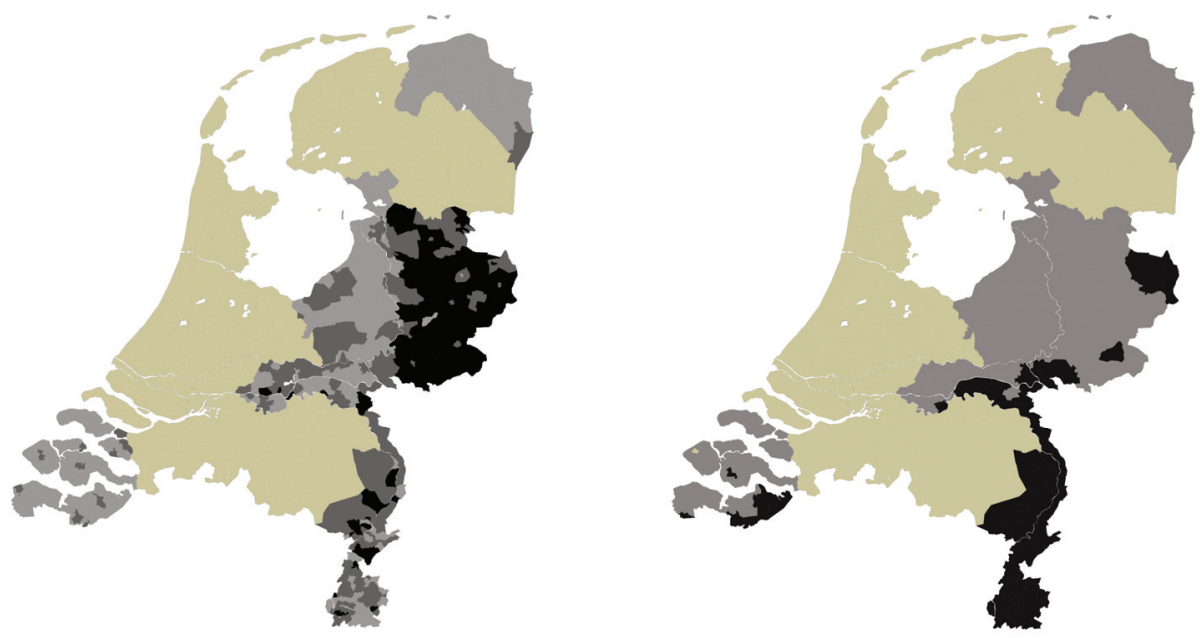
To summarize, we can now formulate the following hypotheses:

1) The developmental cycle of the (peasant) household might have been a more appropriate model in predicting the relation between sibship size and status attainment - particularly for rural populations. We thus expect that for persons from farming or farm laboring backgrounds, the impact of large sibship size on social status at marriage will be less negative or even positive (developmental cycle of the household hypothesis).

2) The negative effect of sibship size on status at marriage is expected to be weaker for persons marrying in communities with stem families, household sharing with kin, and customs of neighbour help. The same relation can be expected for persons marrying in communities with high proportions of Catholics (buffering hypothesis).

3) We expect that with socio-economic development and fertility decline, the impact of sibship size on status at marriage changed from neutral or positive to negative. We expect this to have happened particularly as of the turn of the twentieth century (socioeconomic development and fertility decline hypothesis).

\section{Data}

The main source material for our study is a large-scale database, named Genlias, which contains indexes of marriage certificates. The following data were entered into the database: the date and place of marriage, the surnames and Christian names of the bride and bridegroom, their places of birth, ages and occupations, as well as the surnames, Christian names and occupations of the couple's parents. In the Netherlands, the vital registration system was introduced nation-wide in the years 1811-12. In those parts of the Netherlands that were an integral part of the French Empire during the Napoleonic era (such as the province of Limburg, and parts of Zeeland (Zeeuws-Vlaanderen, or 'Dutch Flanders') the Civil Register was introduced years earlier, in 1796. As the registration system began functioning flawlessly only after several years had elapsed, we excluded all information before 1812 - 1812 being the year in which the whole country had a functioning registration system.

According to the law, marriage records enter the public domain only after 75

years. Therefore, data could only be used for marriages contracted later than 1925 . Complete datasets that included the occupational titles of the groom were only available for five of the eleven Dutch provinces: Zeeland, Limburg, Gelderland, Groningen and Overijssel. The total number of marriages in the database Genlias (version 2007_3) was 
1,110,878, of which approximately 208 thousand were in Groningen, 221 thousand in Overijssel, 327 thousand in Gelderland, 190 thousand in Limburg and 164 thousand in Zeeland. The database representing these five provinces covers around 35 percent of all marriages contracted in the Netherlands in the period between 1812-1925. This coverage is more or less constant over the sample period.

For all persons (brides and grooms) for whom we had a marriage record we reconstructed the size of their sibling set. We first linked their marriage record to the marriage certificate of their parents. This linkage was based on the combination of first and last names of both parents, as given in the child's and the parent's marriage certificates, allowing for small deviations. Both the age and the year of marriage of the child were utilized to calculate the range of the period in which the parents were married (based on the child-bearing period of women). In this way, we could reduce the number of pairs of parents that were eligible for linkage with more than $75 \%$. We tried to link parents and children both within and across provinces. Each record contains information on the bride, the groom and both sets of parents. It stands to reason that information on two generations is most common for people who married after 1900 and that this kind of information would not be available for people who married closer to 1812. In other words, the chance of linkage is higher for children whose parents married recently (because marriages prior to 1796/1812 are not in the registry). This could bias our results and we therefore study status attainment at marriage from 1840 onwards, allowing 28 years for linkage. This resulted in a final number of 946,942 marrying persons.

In the second step, sibling sets containing children with the same father and mother were constructed. In total, we obtained information on 404,872 sibling sets from the Genlias database. These sibling sets contained only those siblings that had married and did not include siblings that never married. In $19^{\text {th }}$ and early $20^{\text {th }}$ century Netherlands, normally one of the children, usually the youngest daughter, remained unmarried in order to care for the parents (Bras and Kok 2003). However, in some social groups it was more customary that children remained unmarried, thus resulting in a possible bias in our estimation of sibship size. For instance, Catholic children might have remained unmarried more often than Protestant children since Catholics looked more favourably on celibacy. Moreover, in larger sibling sets more children might have remained unmarried than in the smaller sibling sets. On the basis of data covering the full life course of all siblings from 237 families in the Dutch community of Akersloot (Kok and Bras 2008), we tested whether this might have been the case (results can be provided by the first author upon request). Of all sibling sets, 70.5 percent were complete, i.e. did not contain any permanent unmarried siblings. In 22.8 percent of all families only one sibling remained unmarried and in 6.7 percent of the sibling sets more than one sibling remained unmarried. The percentage of complete sets did not drop systematically with 
increasing sibship size. Of the Catholic sibling sets 65.6 percent were complete. NonCatholic sibling sets did not significantly differ in this respect. Thus, our measure of taking only married individuals as a proxy did not systematically bias or underestimate sibship size in particular kinds of families.

In addition to the parental background and individual information on each marrying person, we linked community-level data from the Historical Database of Dutch Municipalities. This database stores information from several sources, including the decennial censuses and the provincial reports. We used variables indicating the proportion of Catholics, the percentage of co-residing kin, and the degree of urbanization in the couples' place of marriage. This is the place where the groom actually attained social status by working in a certain occupation. Moreover, particularly in (young) adulthood, that is, at the moment of establishing a household through marriage, buffering has an effect on marriage. In other words, people who were disadvantaged by growing up in a large family could better compensate and attain a relatively higher status if they lived in communities where communal support (religious, kin, or neighbourhood) was available.

\section{Measures}

Our dependent variable measures the bride or groom's social status at marriage. We base this status on the occupation of the groom given on the marriage certificate. In historical research, men's occupations are often used as indicators of social status. Women's occupations can also be used (see for instance Bras 1998) but in the Netherlands, the reporting of female occupations on marriage records differed strongly among regions (Walhout and Van Poppel 2003). Moreover women's social standing was largely determined by the occupations of their fathers and husbands. We classified all occupations of grooms in a social class system applicable for the whole period, called HISCO (Historical International Standard Classification of Occupations) (Van Leeuwen, Maas, and Miles 2002), which is compatible with the International Labor Organization's International Standard Classification of Occupations (ISCO68) scheme. In order to convert these occupational categories to a status score, we applied a stratification scale for the $19^{\text {th }}$ and $20^{\text {th }}$ century, called HISCAM, which is based on the CAMSIS scales, and adapted for HISCO-coded occupational data. ${ }^{7}$

The independent variables are measures of the three explanations of the relationship between sibship size and status attainment. We use social class background as an indicator of the developmental cycle hypothesis and expect that the negative

\footnotetext{
${ }^{7}$ http://www.camsis.stir.ac.uk/hiscam/ (May 20, 2010).
} 
effects of sibship size might be dampened or even be reversed for children from farmers' and farm workers' households.

Social class. The social background of the bride or groom was charted on the basis of information on the father as given in the father's own marriage record. This gives more reliable information than taking the father's occupation from the marriage record of his child (Delger and Kok 1998). As we did with the groom's occupations, we also classified paternal occupations using the HISCO. The occupational categories were further classified into an abridged version of a historical social class scheme proposed by Van Leeuwen and Maas (2005), known as HISCLASS, which employs the following seven categories: higher managers and professionals, lower managers and professionals combined with clerical and sales people, foremen and skilled workers, farmers and fishermen, lower skilled workers, unskilled workers, and farm workers. We collapsed the urban occupational categories and created four major groups: (1) higher and middle classes; (2) farmers; (3) laborers; (4) farm laborers.

We subsequently include indicators that are related to the 'buffering' explanation.

Familism. In areas with a 'familist' family system, i.e. with strong bonds between extended kin and customs of neighbour help, we expect a buffering of the negative effects of large family size. We created a measure of 'familism' on the basis of information from the 1899 census on the percentage of households in the community with co-residing 'others' (spouses, kin and boarders). Because this variable does not measure co-residing kin per se but also includes spouses and boarders, we checked the reliability of this measure against a variable from the 1949 census, which charts only the percentage of co-residing kin. We found a reasonably strong correlation between both measures $(r=0.70 ; p<0.00)$. In the multivariate analyses both indicators yielded approximately the same result, indicating that the variation between the municipalities was mostly due to variation in the percentage of co-residing kin. Additionally, results from previous research on the co-residence of kin in nineteenth-century Netherlands confirm that there was also little change during the period before 1899. Kok and Mandemakers (2009: 151) showed that in the countryside the proportion of co-resident kin changed from $12 \%$ during $1860-1864$ to $11 \%$ during $1885-1899$ while in towns the percentages of co-resident kin changed from $10 \%$ to $12 \%$ during that same period. We opted to include the 1899 variable because it better fits our study period. We ranked all places by the percentage of co-residents in the household. A higher score on this measure is taken as indicative of a more 'familist' family system. In the descriptive analyses we distinguish places in the top $25 \%$ from all other places. 
Catholicism. We also included the proportion of Catholics in the marriage community. We standardized this variable by taking percentile scores. In the descriptive analyses we distinguish places in the top $25 \%$ from all other places.

A third explanation pertains to the changing effect of sibship size with socioeconomic development.

Period. We simply include the marriage year as an indicator of socioeconomic development and fertility decline. In the descriptive analyses we contrast the preindustrial, pre-transition period 1840-1899 with the period 1900-1929 in which fertility declined rapidly and industrialization gained pace.

In order to test whether the effect of sibship size differed across contexts, interactions between sibship size and social classes, familism, Catholicism, and period were included.

As control variables, we included sex, birth order, marriage age, marriage age squared, and migration experience. Birth order was included in order to avoid its possible confusion with sibship size. Some studies (e.g. Black et al. 2005) have found that the effect of sibship size disappears when controlling for parity. In order to chart migration experience, a dichotomous variable was constructed indicating whether the bride or groom had migrated between place of birth and marriage place. Finally we controlled for whether the marriage place was rural or urban. A dichotomous variable was created classifying municipalities into urban or rural based on the percentage of the population working in agriculture in 1889 and the historical designation of a municipality as a town or village.

Table 1 gives an overview of the characteristics of the sample. Couples living in a rural community at the time of marriage dominated; with only 15 percent married in a city. Note also how the social class composition of the sample testifies to the agricultural orientation of the regions under study. Almost half of all brides and grooms came from farmers' or farm workers' background. 
Table 1: Means and percentages of independent variables

\begin{tabular}{|c|c|c|c|c|}
\hline & Min & Max & $\%$ mean & $\begin{array}{l}\text { Standard } \\
\text { deviation }\end{array}$ \\
\hline \multicolumn{5}{|l|}{ Occupational status at marriage } \\
\hline (HISCAM-scale) $(0 . .100)$ & 10.60 & 99 & 47.19 & 11.96 \\
\hline Sex $(0=$ female, $1=$ male $)$ & & & 50 & \\
\hline Sibship size & 0 & 14 & 2.68 & 1.98 \\
\hline Birth order & 1 & 15 & 2.36 & 1.54 \\
\hline Marriage age & 15 & 90 & 26.45 & 5.49 \\
\hline Migrated (0=no, $1=$ yes) & & & 45.88 & \\
\hline \multicolumn{5}{|l|}{ Occupation father } \\
\hline Higher and middle classes & & & 20.56 & \\
\hline Farmers and fishermen & & & 23.50 & \\
\hline Lower skilled and unskilled laborers & & & 15.97 & \\
\hline Farm laborers & & & 21.15 & \\
\hline Father's occupation unknown & & & 18.82 & \\
\hline Urban (0=no, $1=y e s)$ & & & 15 & \\
\hline \% Kin co-residence (percentile score) & .12 & 99.96 & 50 & 28.66 \\
\hline$\%$ Roman-Catholics (percentile score) & 11.50 & 97.60 & 50 & 28.69 \\
\hline Marriage year & 1840 & 1925 & 1892 & 21.03 \\
\hline$N$ of persons & 946,942 & & & \\
\hline$N$ of families & 404,872 & & & \\
\hline$N$ of communities & 402 & & & \\
\hline
\end{tabular}

Source: Database GENLIAS_2007_3; Historical Database Dutch Municipalities; Census 1899: http://www.cbs.nl/nl$\mathrm{nl} /$ menu/themas/dossiers/volkstellingen/cijfers/volkstellingen-1899.

\section{Method}

In studying the relationship between sibship size and status outcomes, problems of endogeneity might play a role. It does seem plausible, even likely, that unobserved characteristics of the birth family that affected family size might also have affected outcomes in adulthood. While controlling for father's occupation addresses one of the most obvious potential sources of endogeneity, i.e. SES, there may have been others. In the recent economics literature, a number of authors have tried to carefully analyze the 
causal effects of sibship size on outcomes by using an instrumental variable (IV) approach. These studies use exogenous variation in family size induced by twin births (Black et al. 2005; Cáceres-Delpiano 2006) or sibling sex composition (Conley and Glauber 2006) to estimate the causal effects of sibship size on status outcomes. However, an IV approach as a solution to endogeneity issues has its limitations; the largest difficulty being the problem of finding a variable that is unrelated with any measurable family background characteristic. Furthermore, although we cannot preclude that the observed relationships reflect endogeneity, we think that it is of less concern in our historical population than in many of the contemporary populations that studies using IV approaches have dealt with. Our analyses cover the period from 1840 to 1925. During the largest part of this period, at least up until ca. 1900, the number of children born to Dutch women, was largely random. Moreover, even during the first phases of the fertility decline, family size differed mainly by social class, a variable for which we control in our analyses. However, we should remain judicious about claiming causality when interpreting the results of our analyses.

We start by describing the association between sibship size and social status and between birth order and social status, paying particular attention to differences in these relationships across social groups and contexts. Next, a series of hierarchical linear regression analyses are performed in order to estimate the effect of sibship size and to test whether the contextual interactions are significant. Because couples from one community share characteristics and are thus more alike than couples from different communities, we applied multilevel analysis (Hox 2002). In this way we compensated for the hierarchical structure of our data, that is, the fact that often more than one marriage couple was nested in a marriage community. If we had applied ordinary regression analysis, not only would the assumption of the independence of the error terms have been violated, but - since large communities would have been represented in larger numbers than communities with only a few couples - we would have overestimated the number of degrees of freedom and the significance of the effects. Multilevel analysis takes both levels, the community and the marrying couple, into account simultaneously (Snijders and Bosker 1999).

In our data, persons (siblings) are also clustered in families. However, the levels of communities, families and individuals are not hierarchically nested. Only in some cases do all siblings from a family marry in the same community. The individuals are thus cross-classified with regard to family and community. Due to the large number of cases (almost a million), estimating cross-classified models was too computationally demanding. Thus, for the multilevel analyses, we created a dataset in which we kept those cases for which all variables were complete. We then randomly drew one sibling from each family, retaining one sibling from each of the 245,065 families for analysis. In this way, the problem of nesting at the family level was avoided. Two-level 
hierarchical linear regression models were then created calculating social status at marriage.

\section{Results}

\subsection{Sibship size and social status at marriage: descriptive results}

Figure 3 shows how status attained at marriage varied by sibship size. With an increasing number of siblings, individual status at marriage fell. Of course we are looking at a descriptive result, which fails to control for other influences, such as social class. For instance when only lower-class families are large, the relationship between sibship size and social status might well be spurious. Moreover, the association between sibship size and status outcomes might differ between social groups, as we argue in this paper.

Figure 3: Average occupational status (of groom) by sibship size

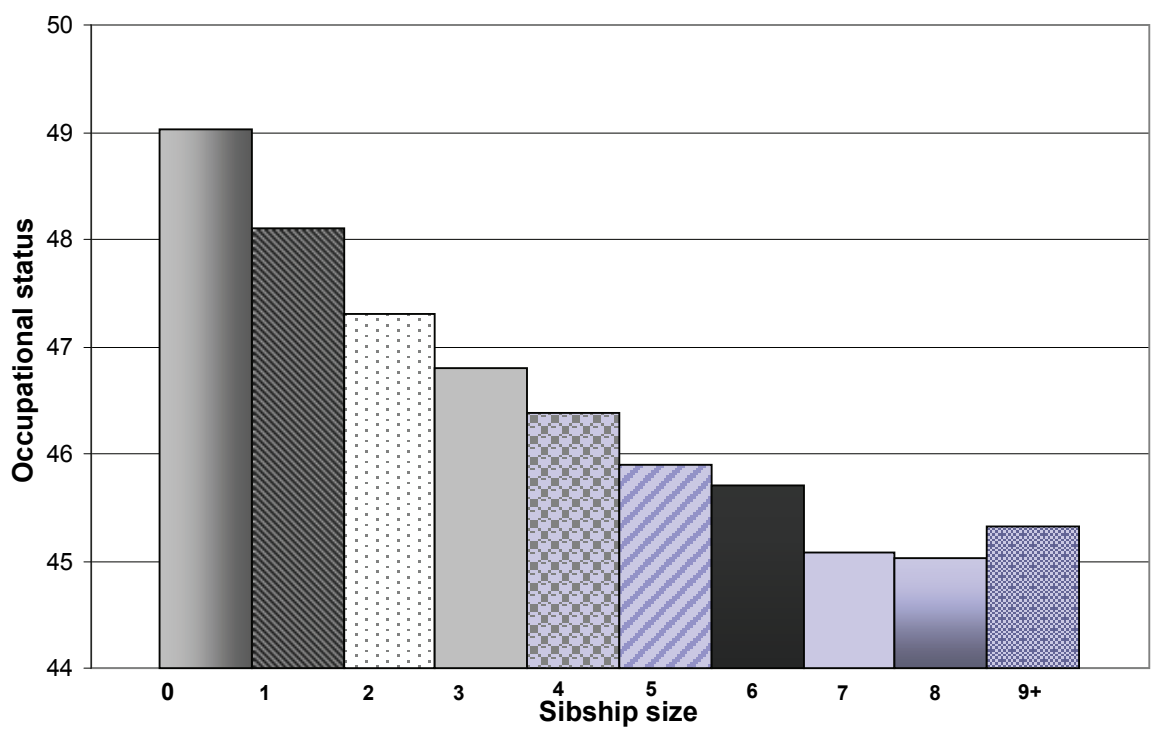


In Figure 4 we lift a first tip of the veil by presenting average occupational status by sibship size for different social groups and contexts. We expected that resource dilution played a larger role in the higher and middle classes and in the urban laboring class. Thus, in these groups we surmise that the larger the family, the smaller the piece of the pie for each individual child, resulting in decreased status. In the top panel of Figure 4, differences in the sibship size-status relationship between social groups become apparent. Among the higher and middle classes and among the (urban) laborers, differences in achieved status at marriage between children originating in families with different sibship sizes are indeed larger and more pronounced. Conversely, among those from farmers' families and farm laborers' families, family size does not seem to matter so much in determining the status that men and women attained at marriage.

Figure 4: Average occupational status by sibship size, by (1) social class and (2) familism, Catholicism, and period

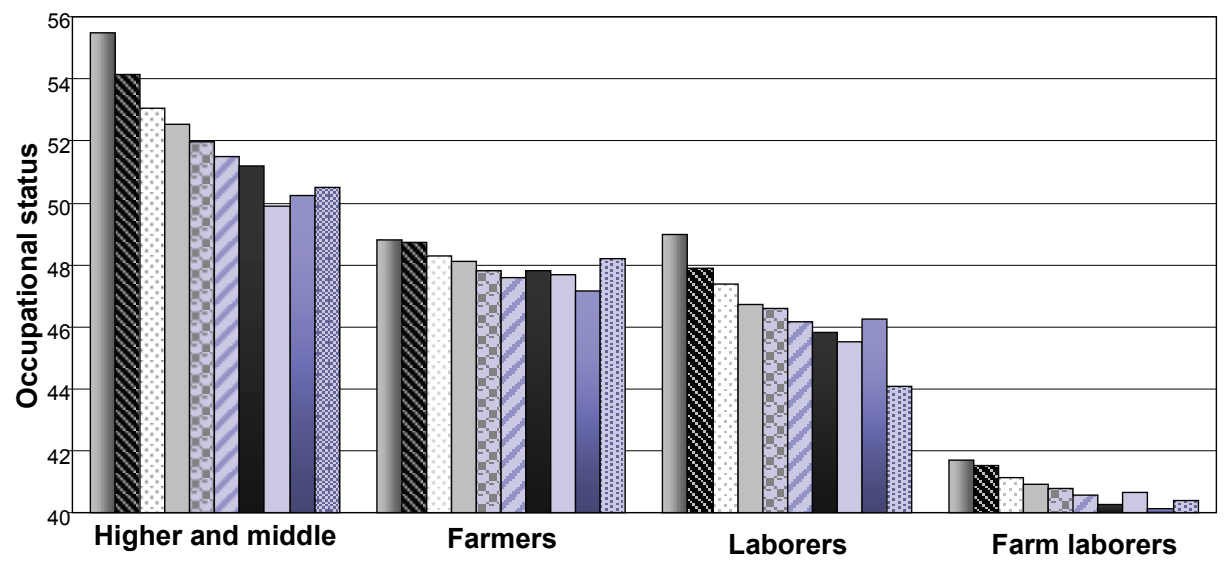


Figure 4: (continued)

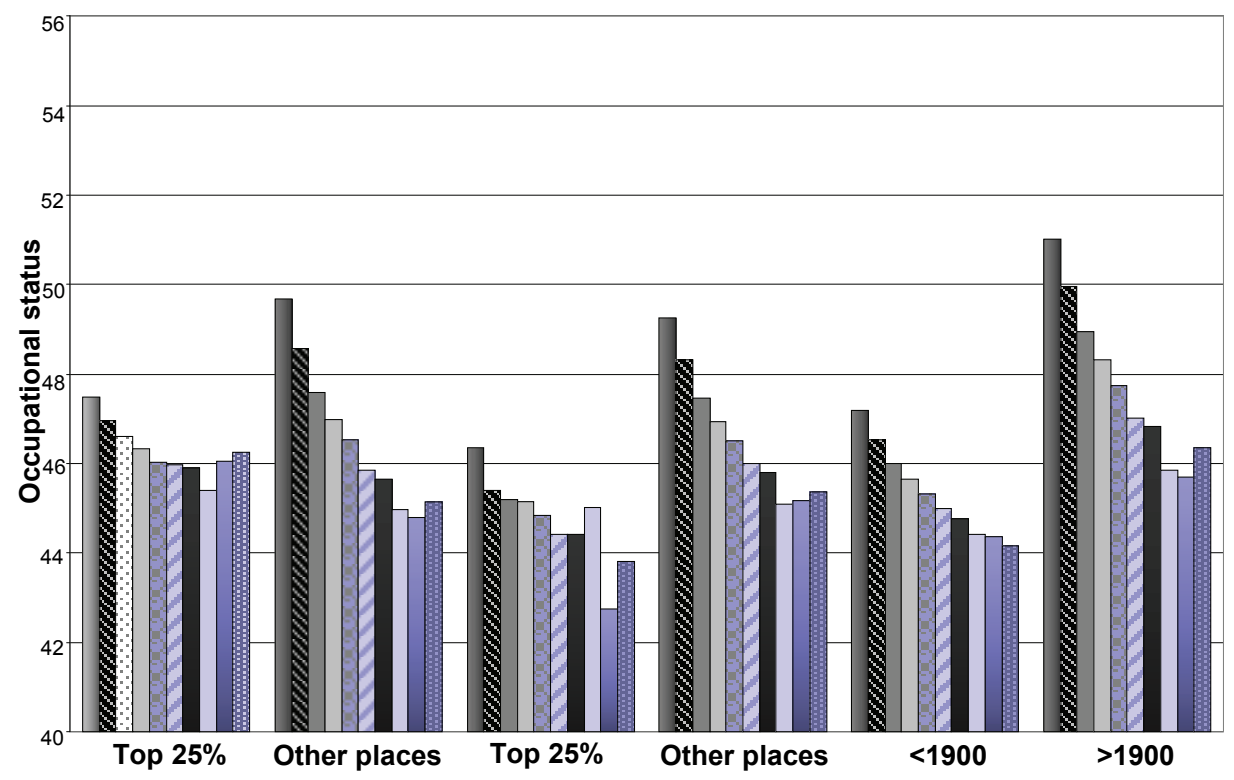

A similar phenomenon can be observed when we consider the difference between men and women marrying in places with and without a 'familist' family system. We expected that in 'familist' areas buffering by wider kin and neighbours played a role resulting in a less negative impact of sibship size on social status. As can be observed at a glance, the divergence in attained status between individuals from small and large families is much smaller in the familist area.

Our expectation with regard to the influence of Catholicism seems also borne out by the data. The Catholic Church propagated large families and Dutch Catholic organizations spread pronatalist and pro-family norms and offered moral, and after 1917, material support to large Catholic families. In largely Catholic communities the life chances of men and women seem to have been less hampered by large families of origin. Finally, the Figure shows that the status differential among children from small and large families is greater after 1900 than it is during the second part of the nineteenth century. By 1900 socioeconomic development had sped up, while fertility had started to decline. The findings in Figure 4 generally seem to be in line with our hypotheses. Multivariate analysis is of course needed to ascertain the statistical significance of these group differences when controlling simultaneously for the effects of the other variables. 


\subsection{Multivariate analysis}

We created two hierarchical linear models estimating the effects of sibship size (Table 2, model 1) and sibship size and its interactions with social class, familism, Catholicism and period (Table 2, model 2). It is clear from Model 1 that the effect of sibship size is negative, even when we control for parental social class. The magnitude of the sibship size effect is rather large. With each additional sibling a child loses almost half a point on the HISCAM-scale, which ranges from 11 to 99. An additional four siblings means a loss of 2 points in social status - equal to the difference between originating from a farmer's or from a laborer's background in attained status at marriage.

We also observe significant effects of the control variables in Model 1. The effect of birth order is positive and highly significant. With each higher parity, one's social status at marriage improves by more than a quarter point on the HISCAM-scale. On average females attain a higher social status at marriage than men. Hypergamy has been found elsewhere in studies of intergenerational mobility during the nineteenth century (Van Bavel 2005) and it has been argued that this was an essential characteristic of the kinship regimes of European societies in the nineteenth and early twentieth centuries (Sabean 1998). We find a curvilinear effect of age at marriage on status at marriage. Very young and very old grooms and brides apparently did worse. On average, migrants attain a higher social status at marriage. In our largely rural study area, migrants might have represented a positively selected group. As expected, parental social class is also a strong determinant of status at marriage; with the gap between the higher / middle classes and farmers being particularly wide. The discrepancy in attained status between laborers and farm laborers even amounts to five points in the HISCAMscale. Not surprisingly, in urban places social status attained at marriage was higher. In communities with high percentages of co-residing kin social status attained at marriage was lower than in communities in which stem families and extended family were less relevant. The stem family area in the Netherlands coincided with the sandy-soil area in the east and south where small-scale family farming was practiced and social structure was less polarized than in the sea-clay provinces of Zeeland and Groningen. However, opportunities for upward social mobility were rarer in these communities, as well. A higher proportion of Catholics in the marriage community meant a substantial drop on the social ladder. In a Swiss study, Praz (2006) found that Catholics invested less in the education of their children than Protestants. Likewise a Dutch study on social mobility in the first half of the 20th century suggested that lower rates of upward mobility found among Catholics, after controlling for family size, could be explained by lower levels of education (Van Tulder 1962: 140). Finally, with each year later between 1840 and 1925 average status at marriage improved, reflecting the upward trend in occupational status that was presented in Figure 1. 
Table 2: Hierarchical linear models estimating the effects of sibship size on occupational status at marriage $(N=\mathbf{2 4 5 , 0 6 5})$

\begin{tabular}{|c|c|c|c|c|c|c|}
\hline \multirow[b]{2}{*}{ Covariates } & \multicolumn{3}{|c|}{ Model 1: sibship size } & \multicolumn{3}{|c|}{$\begin{array}{c}\text { Model 2: } \begin{array}{c}\text { sibship size } 8 \\
\text { interactions }\end{array}\end{array}$} \\
\hline & $\mathbf{b}$ & s.e. b & & $\mathbf{b}$ & s.e. b & \\
\hline Sibship size & -0.45 & $(0.02)$ & \multirow[b]{2}{*}{$* \star \star$} & 14.66 & (1.39) & \multirow[b]{2}{*}{$* * *$} \\
\hline Birth order & 0.26 & $(0.03)$ & & 0.30 & $(0.03)$ & \\
\hline Sex $(0=$ female, $1=$ male $)$ & -0.53 & $(0.05)$ & \multirow[b]{2}{*}{$* * *$} & -0.52 & $(0.05)$ & \multirow{2}{*}{$m \times$} \\
\hline Marriage age & 0.86 & $(0.03)$ & & 0.86 & $(0.03)$ & \\
\hline Marriage age squared & -0.01 & $(0.00)$ & \multirow{2}{*}{$\begin{array}{l}\pi \times \pi \\
\pi * *\end{array}$} & -0.01 & $(0.00)$ & \multirow{2}{*}{$\pi \times$} \\
\hline Migrated $(0=$ no, $1=$ yes $)$ & 0.57 & $(0.05)$ & & 0.55 & $(0.05)$ & \\
\hline \multicolumn{7}{|l|}{ Occupation father } \\
\hline Higher/middle (unknown=ref.) & 7.63 & $(0.09)$ & $\times \times$ & 8.12 & $(0.12)$ & $\pi \times$ \\
\hline Farmers and fishermen & 3.64 & $(0.09)$ & $* * *$ & 3.62 & $(0.13)$ & $* \star *$ \\
\hline Laborers & 1.84 & $(0.09)$ & \multirow{2}{*}{$* * *$} & 2.18 & $(0.13)$ & $\times x \times$ \\
\hline Farm laborers & -3.04 & $(0.09)$ & & -3.11 & $(0.13)$ & $* n *$ \\
\hline Urban $(0=$ no, $1=y e s)$ & 2.00 & $(0.58)$ & \multirow{2}{*}{${ }^{x \times x}$} & 1.99 & $(0.58)$ & \multirow{2}{*}{$\times x \times$} \\
\hline$\%$ Kin co-residence & -0.02 & $(0.01)$ & & -0.03 & $(0.01)$ & \\
\hline \% Roman-Catholics & -0.01 & $(0.00)$ & \multirow{2}{*}{$\times n$} & -0.01 & $(0.00)$ & \multirow{2}{*}{$n \times$} \\
\hline Marriage year & 0.07 & $(0.00)$ & & 0.09 & $(0.00)$ & \\
\hline \multicolumn{7}{|l|}{ Interactions } \\
\hline Higher/middle * sibship size & & & & -0.31 & $(0.05)$ & $\mathrm{nx}$ \\
\hline Farmers * sibship size & & & & -0.01 & $(0.05)$ & \multirow[b]{2}{*}{ 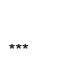 } \\
\hline Laborers * sibship size & & & & -0.21 & $(0.05)$ & \\
\hline Farm laborers * sibship size & & & & 0.01 & $(0.05)$ & \multirow[b]{2}{*}{$* * *$} \\
\hline$\%$ Kin co-residence * sibship size & & & & 0.00 & $(0.00)$ & \\
\hline$\%$ Catholics * sibship size & & & & 0.00 & $(0.00)$ & \\
\hline Marriage year * sibship size & & & & -0.01 & $(0.00)$ & $* \star \star$ \\
\hline \multicolumn{7}{|l|}{ Random part } \\
\hline Std. dev. community level & 2.54 & $(0.16)$ & & 2.55 & $(0.16)$ & \\
\hline Std. dev. individual level & 11.25 & $(0.02)$ & & 11.24 & $(0.02)$ & \\
\hline
\end{tabular}

${ }^{* * *} p<0.001{ }^{* *} p<0.01{ }^{*} p<0.05$.

Source: as in Table 1. 
In Model 2 we added interactions in order to test whether the relationship between sibship size and social status was moderated by social class, Catholicism, familism and socio-economic development (period). Adding the interactions only marginally changes the effects of the control variables. The interactions with social class, familism and period are significant, and in the expected direction thus confirming our hypotheses. In Figure 5, predicted regression lines visually show the effects of sibship size on marriage status. All else being equal, panel 1 depicts differences across the four different social classes; panel 2 depicts differences based on familist versus non-familist community value system; and panel 3 depicts differences in pre- versus post-transition Netherlands.

Figure 5: $\quad$ Regression lines predicting attained social status at marriage by sibship size for (1) different social groups, (2) high/low kin coresidence, and (3) pre- and post-transition Netherlands

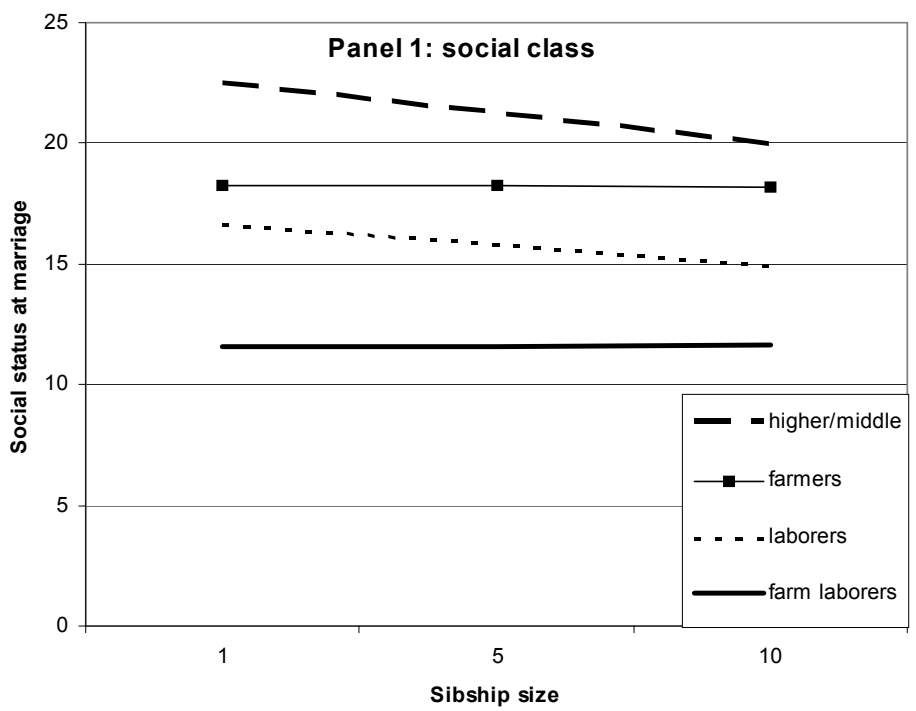




\section{Figure 5: (Continued)}
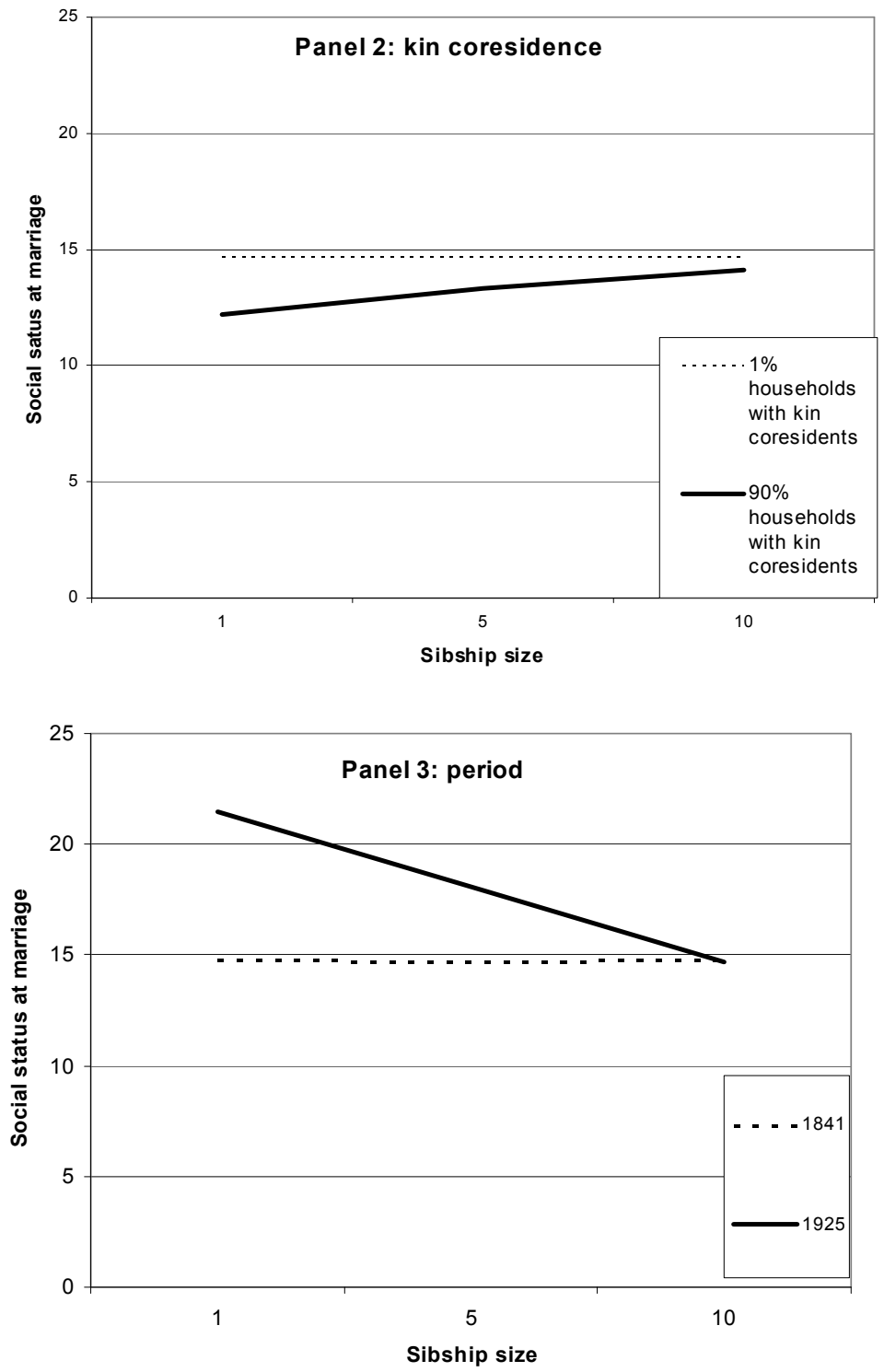
Panel 1 shows that while individuals from the higher and middle classes on average attained the highest occupational status at marriage, their prospects in life were the most influenced by the size of their sibship compared to individuals from other social groups (the dotted line of the higher/middle class is negative and the steepest of all). Individuals from large families clearly attained lower social status than individuals from small families. Individuals from the urban laboring class were better off as well when they had only a few siblings. This negative association between sibship size and status at marriage did not hold, however, for children from farmers' and farm laborers' households. In these rural social groups large family size was not detrimental for status outcomes at marriage.

Panel 2 depicts the predicted occupational status of individuals marrying in an area where a 'familist' family system was extant (i.e. top $10 \%$ of places with most kin-coresidence) versus the situation of individuals marrying in an area where stem families and neighborly help were absent (bottom 1\%). The picture confirms what we also saw in Model 1 of Table 2; namely that individuals in stem family areas do worse, on average. However, in areas with tight-knit kin and neighborhood networks, large sibship size has the opposite effect of what we might expect on the basis of resource dilution; a larger sibling group enhances children's status outcomes at marriage. Conversely, individuals marrying in places with almost no communal resources were not affected by the size of their sibship, that is, after controlling for all other factors influencing status at marriage.

The interaction between marriage year and sibship size shows how the effect of sibship size on status at marriage is moderated according to the degree of socioeconomic development. The interaction effect is negative, corroborating our expectation that in the course of socioeconomic development and fertility decline, resource dilution became increasingly important. Panel 3 shows this clearly. On average, marriage in 1925 meant a higher status at marriage than marriage in 1841. In 1841 it did not really matter for one's marriage prospects whether one originated from a small or a large family. Conversely, in 1925, it surely did. Having 10 siblings in 1925 meant the same predicted status at marriage as someone marrying in 1841 (all other things equal). Over time, family size may thus have become an increasingly important regulator of people's life chances.

\section{Conclusion and discussion}

The record of empirical evidence regarding the effects of sibship size on status outcomes is mixed. Contradictory findings from developed and developing countries suggest that there are different mechanisms at work in the relationship between sibship 
size and status outcomes. Apart from the resource dilution hypothesis, which states that resources are diluted when sibship size is greater, we outlined three alternative mechanisms.

A household's phase in the developmental cycle, which is strongly related to sibship size, might explain why the effect of large families is neutral or even positive, in some cases. When resource flows go from children to parents, large sibship size means more children that can contribute to the family budget. Moreover, when the eldest children work or migrate and send remittances, the youngest children are set free for education or alternative employment, thus enhancing their status later in life. A second explanation concerned the buffering role of community, extended kin bonds and of institutions like the Catholic Church. A lack of resources in the family might be compensated for by external groups, thus attenuating the negative effects of large family size. Finally, the effects of sibship size might actually change over time in relation to a country's socioeconomic development and fertility decline. With industrialization and the limitation of families, the resource dilution explanation might have become increasingly important as an explanatory mechanism, with families increasingly investing in the education and human capital of a smaller number of children.

In this paper we have tested all of these mechanisms with one large-scale database covering a large, but mostly rural, part of the Netherlands over the 80 years between 1840 and 1925, including pre-transition, pre-industrial, as well as post-transition, industrialized Netherlands. Our findings show that the relationship between sibship size and social status differed strongly across contexts and subgroups. Providing support for the hypothesis of the household developmental cycle are the findings that sibship size had no detrimental impact on children from farmers' and farm laborers' households. Buffering by neighborhood helping systems, extended kin groups, and the Catholic Church is partly borne out by the data. In areas with high proportions of co-residing kin the impact of larger family size on status at marriage is positive. We did not find the effects of large sibship size to be significantly less disadvantageous in largely Catholic communities than in other places. Finally, we found evidence supporting the idea that the mechanisms beneath the association between sibship size and social status changed over time. In the course of socioeconomic development and fertility decline, resource dilution became more important in that larger sibship size more negatively impacted an individual's outcomes at marriage.

Our study has a number of limitations. A first limitation is the fact that we measured sibship size on the basis of the number of married siblings. Although we have good reasons to believe that this proxy does not bias certain types or sizes of families, it would have been better if we could have relied on data from complete sibling sets. This would also have allowed us to consider the influence of family size on the particular life 
chances of unmarried individuals. Secondly, the studied association between family size and status outcomes might well be plagued by problems of endogeneity masking true causality. However, given that the number of children was still largely random in pretransitional Netherlands and was mainly differentiated by social class during the demographic transition, endogeneity issues are likely to be less important in this historical population then in some contemporary populations. Nevertheless, we have remained modest when interpreting significant associations in this study in terms of causality. Finally, since we did not have a measure of individual religious affiliation, i.e. Catholicism, we used the proportion Catholics at the community level. Although individual measures are preferable, in a largely Catholic region, even non-Catholics might be influenced by the norms, values and resources offered by the dominant religion.

Desai (1995: 196) has pointed out that the resource dilution thesis is based on three assumptions: "(1) Parents, rather than the state or extended kin groups, provide the bulk of economic and non-economic resources available to children; (2) Parental resources, rather than external social institutions, are important determinants of children's wellbeing; (3) The resources available for consumption by children within the family are fixed, and do not depend on the total number of children". Our results, as well as some previous findings, have made it clear that these assumptions are not valid in all social contexts and might even change over time. Indeed, other mechanisms regarding family size exist and produce highly different results for people's outcomes and well-being. Although our paper is based on historically and geographically specific data, our results might be applicable to fertility and well-being programs in other cases, including contemporary developing countries.

\section{Acknowledgements}

This publication is part of the proposed Special Collection "Social Mobility and Demographic Behaviour: A Long-Term Perspective", organized by guest editors Cameron Campbell, Jan Van Bavel, and Martin Dribe. The papers in the Special Collection were presented at a seminar at the University of California, Los Angeles organized by the IUSSP Scientific Panel on Historical Demography and hosted by the UCLA California Center for Population Research. The seminar received support from the IUSSP as well as a number of units at UCLA, including the International Institute, the Center for Economic History, the California Center for Population, the Office of the Dean of Social Sciences, and the Irene Flecknoe Ross Lecture Series in the Department of Sociology. 


\section{References}

Adams, J.W. and Kasakoff, A.B. (1992). The farm family economy in the American North, 1775-1875: an exploration of sibling differences. Continuity and Change 7(3): 357-375. doi:10.1017/S0268416000001715.

Bayer, A.E. (1967). Birth Order and Attainment of the Doctorate: A Test of Economic Hypotheses. American Journal of Sociology 72(5): 540-550. doi:10.1086/224383.

Becker, G.S. (1991). A Treatise on the Family. Enlarged Edition. Cambridge, MA: Harvard University Press.

Berkner, L. (1972). The Stem Family and the Developmental Cycle of the Peasant Household: An Eighteenth-Century Austrian Example. The American Historical Review 77(2): 398-418. doi:10.2307/1868698.

Black, S.E., Devereux, P.J., and Salvanes, K.G. (2005). The More the Merrier? The Effect of Family Size and Birth Order on Children's Education. The Quarterly Journal of Economics 120(2): 669-700. doi:10.1162/0033553053970179.

Blake, J. (1981). Family Size and the Quality of Children. Demography 18(4): 421-442. doi:10.2307/2060941.

Blake, J. (1989). Family Size and Achievement. Berkeley: University of California Press.

Boonstra, O.W.A. and Van der Woude, A.M. (1984). Demographic transition in the Netherlands. A statistical analysis of regional differences in the level and development of the birth rate and of fertility, 1850-1890. A.A.G. Bijdragen 24: $1-57$.

Bott, E. (1957). Family and Social Networks. Roles, Norms, and External Relationships in Ordinary Urban Families. London: Tavistock Publications.

Bras, H. (1998). Domestic Service, Migration and the Social Status of Women at Marriage. The Case of a Dutch Sea Province, Zeeland 1820-1935. Historical Social Research 23(3): 3-19.

Bras, H. (2003). Maids to the city: migration patterns of female domestic servants from the province of Zeeland, the Netherlands (1850-1950). The History of the Family: An International Quarterly 8(2): 217-246. doi:10.1016/S1081602X(03)00027-7. 
Bras, H. and Kok, J. (2003). 'Naturally, Every Child Was Supposed to Work'. Determinants of the Leaving Home Process in The Netherlands, 1850-1940. In: Van Poppel, F., Oris, M., and Lee, J. (eds.). The Road to Independence. Leaving Home in Western and Eastern Societies, 16th-20th Centuries. Bern: Peter Lang.

Bras, H. and Van Tilburg, T. (2007). Kinship and Social Networks: A Regional Analysis of Sibling Relations in Twentieth-Century Netherlands. Journal of Family History 32(3): 296-322. doi:10.1177/0363199007300244.

Buchmann, C. and Hannum, E. (2001). Education and Stratification in Developing Countries: Review of Theories and Research. Annual Review of Sociology 27(1): 77-102. doi:10.1146/annurev.soc.27.1.77.

Cáceres-Delpiano, J. (2006). The Impacts of Family Size on Investment in Child Quality. Journal of Human Resources 41(4): 738-754.

Chayanov, A.V. (1966). The Theory of the Peasant Economy. Homewood, Ill.: Irwin.

Coleman, J.S. (1988). Social Capital in the Creation of Human Capital. American Journal of Sociology 94(S1): S95-S120. doi:10.1086/228943.

Conley, D. (2005). The Pecking Order. A Bold New Look at How Family and Society Determine Who We Become. New York: Vintage Books.

Conley, D. and Glauber, R. (2006). Parental Educational Investment and Children's Academic Risk. Estimates of the Impact of Sibship Size and Birth Order from Exogenous Variation in Fertility. The Journal of Human Resources 41(4): 722737.

Davis, J.N. (1997). Birth Order, Sibship Size and Status in Modern Canada. Human Nature 8(3): 205-230. doi:10.1007/BF02912492.

Delger, H. and Kok, J. (1998). Bridegrooms and biases: a critical look at the study of intergenerational mobility on the basis of marriage certificates. Historical Methods 31(3): 113-121. doi:10.1080/01615449809601194.

Desai, S. (1995). When Are Children from Large families Disadvantaged? Evidence from Cross-National Analyses. Population Studies 49(2): 195-210. doi:10.1080/ 0032472031000148466.

Downey, D.B. (1995). When Bigger Is Not Better: Family Size, Parental Resources, and Children's Educational Performance. American Sociological Review 60(5): 746-761. doi:10.2307/2096320. 
Downey, D.B. (2001). Number of Siblings and Intellectual Development. The Resource Dilution Explanation. American Psychologist 56(6/7): 497-504. doi:10.1037/0003-066X.56.6-7.497.

Downey, D.B. and Neubauer, S. (1998). Is resource dilution inevitable? The association between number of siblings and educational achievement across subgroups. Paper presented at the $93^{\text {rd }}$ Annual Meeting of the American Sociological Association. San Francisco.

Dumont, A. (1890). Dépopulation et civilisation: étude démographique. Paris: Economica.

Elder, G.H. (1962). Adolescent Achievement and Mobility Aspirations. Chapel Hill: Institute for Research in Social Science.

Eloundou-Enyegue, P.M. and Williams, L.B. (2006). Family Size and Schooling in Sub-Saharan African Settings: A Reexamination. Demography 43(1): 25-52. doi:10.1353/dem.2006.0002.

Gomes, M. (1984). Family Size and Educational Attainment in Kenya. Population and Development Review 10(4): 647-660. doi:10.2307/1973285.

Hermalin, A., Seltzer, J., and Lin, C.-H. (1982). Transitions in the Effect of Family Size on Female Educational attainment: The Case of Taiwan. Comparative Education Review 26(2): 254-270. doi:10.1086/446293.

Höllinger, F. and Haller, M. (1990). Kinship and Social Networks in Modern Societies: A Cross-Cultural Comparison Among Seven Nations. European Sociological Review 6(2): 103-124.

Hox, J. (2002). Multilevel Analysis. Techniques and Applications. Mawah NJ: Lawrence Erlbaum Associates.

Kasarda, J.D. and Billy, J.O.G. (1985). Social Mobility and Fertility. Annual Review of Sociology 11(1): 305-328. doi:10.1146/annurev.so.11.080185.001513.

Kok, J. and Bras, H. (2008). Clustering and Dispersal of Siblings in the North-Holland Countryside, 1850-1940. Historical Social Research 33(3): 278-300.

Kok, J. and Mandemakers, K. (2009). 'Je zoudt maar last van mij hebben' Verwanten in het Nederlandse huishouden, 1860-1940. Tijdschrift voor Sociale en Economische Geschiedenis 6(4): 139-165. 
Lu, Y. and Treiman, D.J. (2008). The Effect of Sibship Size on Educational Attainment in China: Period Variations. American Sociological Review 73(5): 813-834. doi:10.1177/000312240807300506.

Maralani, V. (2008). The Changing Relationship Between Family Size and Educational Attainment Over the Course of Socioeconomic Development: Evidence From Indonesia. Demography 45(3): 693-717. doi:10.1353/dem.0.0013.

Park, H. (2008). Public policy and the effect of sibship size on educational achievement: A comparative study of 20 countries. Social Science Research 37(3): 874-887. doi:10.1016/j.ssresearch.2008.03.002.

Praz, A.-F. (2006). State institutions as mediators between religion and fertility: A comparison between two Swiss regions, 1860-1930. In: Derosas, R. and Van Poppel, F. (eds.). Religion and the Decline of Fertility in the Western World. New York: Springer: Pp. 147-176. doi:10.1007/1-4020-5190-5_8.

Razzaque, A., Streatfield, P.K., and Evans, A. (2007). Family Size and Children's Education in Matlab, Bangladesh. Journal of Biosocial Science 39(2): 245-256. doi:10.1017/S0021932006001398.

Righart, H. (1986). Moraliseringsoffensief in de Nederlanden in de periode 1850-1880. In: Peeters, H.F.M., Dresen-Coenders, L., and Brandenbarg, T. (eds.). Vijf eeuwen gezinsleven. Liefde, huwelijk en opvoeding in Nederland. Nijmegen: SUN. Pp. 163-193.

Sabean, D.W. (1998). Kinship in Neckarhausen, 1700-1870. Cambridge: Cambridge University Press.

Shavit, Y. and Pierce, J.L. (1991). Sibship Size and Educational Attainment in Nuclear and Extended Families: Arabs and Jews in Israel. American Sociological Review 56(3): 321-330. doi:10.2307/2096107.

Sleebe, V. (1998a). Burenhulp tussen 1800 en 1890. In: van Gerwen, J. and van Leeuwen, M.H.D (eds.). Studies over zekerheidsarrangementen. Risico's, risicobestrijding en verzekeringen vanaf de Middeleeuwen. Amsterdam: Nederlands Economisch Historisch Archief.

Sleebe, V. (1998b). Burenhulp tussen 1890 en 1950. In: van Gerwen, J. and van Leeuwen, M.H.D (eds.). Studies over zekerheidsarrangementen. Risico's, risicobestrijding en verzekeringen vanaf de Middeleeuwen. Amsterdam: Nederlands Economisch Historisch Archief. 
Snijders, T.A.B. and Bosker, R.J. (1999). Multilevel analysis. An introduction to basic and advanced multilevel modeling. London/Thousand Oaks /New Dehli: Sage Publications.

Steelman, L.C., Powell, B., Werum, R., and Carter, S. (2002). Reconsidering the Effects of Sibling Configuration: Recent Advances and Challenges. Annual Review of Sociology 28(1): 243-269. doi:10.1146/annurev.soc.28.111301. 093304.

Sudha, S. (1997). Family Size, Sex Composition and Children's Education: Ethnic Differentials over Development in Peninsular Malaysia. Population Studies 51(2): 139-151. doi:10.1080/0032472031000149876.

Todd, E. (1985). The Explanation of Ideology. Family Structures and Social Systems. Oxford: Basil Blackwell.

Todd, E. (1987). The Causes of Progress. Culture, Authority and Change. Oxford: Basil Blackwell.

Todd, E. (1990). L'invention de l'Europe. Paris: Éditions du Seuil.

Van Bavel, J. (2005). The Effect of Fertility Limitation on Intergenerational Social Mobility: The Quality-Quantity Trade-off during the Demographic Transition. Journal of Biosocial Science 38(4): 553-569. doi:10.1017/S0021932005026994.

Van Leeuwen, M.H.D. and Maas, I. (2005). A short note on HISCLASS. http://historyofwork.iisg.nl/docs/hisclass-brief.doc (May 20, 2010).

Van Leeuwen, M.H.D., Maas, I., and Miles, A. (2002). HISCO. Historical International Standard Classification of Occupations. Leuven: Leuven University Press.

Van Tulder, J.M.M. (1962). De beroepsmobiliteit van Nederland van 1919 tot 1954. Een sociaal-statistische studie. Leiden: Stenfert Kroese.

Van Zanden, J.L. and Van Riel, A. (2004). The Strictures of Inheritance: The Dutch Economy in the Nineteenth Century. Princeton: Princeton University Press.

Verduin, J.A. (1985). Het gezin in demografisch perspectief. In: Kooy, G.A. (ed.). Gezinsgeschiedenis: vier eeuwen gezin in Nederland. Assen: Van Gorcum.

Walhout, E. and Van Poppel, F. (2003). 'De vermelding des beroeps: eene ijdele formaliteit?': twee eeuwen vrouwelijke beroepsarbeid in Nederlandse huwelijksakten. Tijdschrift voor Sociale Geschiedenis 29(3): 31-332. 
Wall, R. (1996). Marriage, residence, and occupational choices of senior and junior siblings in the English past. The History of the Family. An International Quarterly 1(3): 259-271.

$\mathrm{Xu}$, J. (2008). Sibship Size and Educational Achievement: The Role of Welfare Regimes Cross-Nationally. Comparative Education Review 52(3): 413-436. doi:10.1086/588761.

Yu, W.-H. and Su, K.-H. (2006). Gender, Sibship Structure, and Educational Inequality in Taiwan: Son Preference Revisited. Journal of Marriage and Family 68(4): 1057-1068. doi:10.1111/j.1741-3737.2006.00313.x. 
Bras, Kok \& Mandemakers: Sibship size and status attainment across contexts 